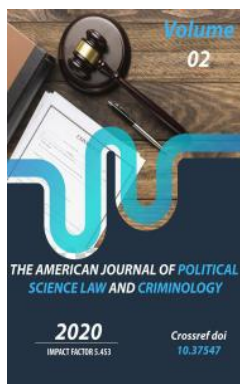

\title{
Particular Features Of Making, Amending And Cancelling Pecuniary Service Contracts With The Participation Of The Internal Affairs Organs
}

Makhmudkxodjayeva Umida Muminovna

MIA Academy Of The Republic Of Uzbekistan

\section{ABSTRACT}

This article analyzes the particular features of making, amending and cancelling pecuniary service contracts with the participation of the internal affairs organs, and develops scientific-theoretical proposals and recommendations.

\section{KEYWORDS}

Pecuniary service contract, making a contract, amending contract, terminating contract.

\section{INTRODUCTION}

The subject of the pecuniary services contract is considered the "services" that are not in the material form, according to the civil law. Pecuniary first appeared in English in the early 16th century and comes from the Latin word pecunia, which means "money." Both this root and Latin peculium, which means "private property," are related to the Latin noun for cattle, pecus. In early times, cattle were viewed as a trading commodity (as they still are in some parts of the world), and property was often valued in terms of cattle. Pecunia has also given us impecunious, a word meaning "having little or no money," while peculium gave us peculate, a synonym for "embezzle." In peculium you might also recognize the word peculiar, which originally meant "exclusively one's own" or "distinctive" before acquiring its current meaning of "strange." 


\section{MATERIAL AND METHODS}

Various methods and materials have been used to define pecuniary service. Research materials prepare a valid argument and explanation to pecuniary service. For quick facts we use reference materials such as encyclopedias, almanacs, or dictionaries in the following. Furthermore, survey, interviews, experiments and their results are used in the following

\section{RESULTS}

To illuminate the statement, it is the activity carried out by people with certain specialization, qualification, which is related to the performance of certain actions or the performance of certain activity, aimed at meeting the needs of individuals [1] . Therefore, the legal features of the contract can be seen in the following:

Firstly, pecuniary service contract can be both consensual and real, depending on the type of service. For instance, hairdressing service can be more realistic while the patrol post service of the internal affairs bodies and the provision of public order and public safety services in the crowded places with the participation of legal entities are consensual.

Secondly, pecuniary service contract is carried out for the fee as in its own appellation. In this case, the customer undertakes to pay for the services performed by the executor in accordance with its requirement s.

Thirdly, pecuniary service contract is a type of bilateral agreement because the sides have both the rights and obligations in such contract.

It can be seen from the above-mentioned legal features that the rules of oral and written forms of contracts are followed in the conclusion of pecuniary service contracts. Pecuniary service contracts with the participation of the internal affairs bodies are required to be in the written form, due to the internal affairs bodies have the status of legal entities. As Kh.R. Rakhmonkulov noted, the completeness of the content of any contract depends on many respects on the legality and accuracy of its terms, as well as the extent to which these requirements are met [2]. It should be noted that the principle of freedom of contract plays a $\mathrm{n}$ important role in making a contract in accordance with Article 354 of the civil code. Freedom of contract is apparent as the decisive basis of civil right, in which the contract states that the parties enter into the relationship in the truly free, voluntary manner. The contract is the basis for the organization of economic relations of independent entities [3].

It is essential to reach the following agreement between the customer and the executor in making pecuniary service contracts. When making pecuniary service contract, the sides express the genuine desire and willingness to enter into a contractual relationship, first of all, in the act of concluding the contract, second of all, in determining the terms of the contract, and last but not the at least in the performance of contractual obligations. Furthermore, the following aspects should be taken into consideration, such as mutual consent and equality of the sides of the contract; the subject of the contract; the rights and obligations of the sides; the payment for services; the term of the contract; the obligation of the sides of contract; the responsibility of the side s; and addressing conflicts in the court. The subject of the contract is services that are not in the material form. Services can be divided into the action and the activity. That is, an activity performed 
by people such as a person who has certain specialization, qualification, which is related to the performance of certain actions (meaning disposable service) or the performance of a certain activity (meaning multi-time or longterm service)), aimed at meeting the needs of individuals. It should be stressed that it is arguably that services are the object of Civil law in the Scientific research of civil- Scholars on the doctrinal interpretation of the subject of this contract.

\section{DISCUSSION}

In our opinion, the specific features of the subject of pecuniary service contract are interrelated with the subject of the contract for the performance of work, including the fact that some scholars imply that "the fruitful result of the service actions are the material, however they are not in the material-substance form "[4], " according to the rule, the action itself is the subject, not the material result of the action" [5], "in the provision of services, one of the counterparts entrusts the other with the performance of certain activities not related to the organization of the material result, but aimed at achieving various other results" [6], " the performance of certain actions or activities is the particular features of pecuniary services"[7], "the individual subject of such contracts should not be the material objects"[8], "the subject of pecuniary service contract may be other services, the law does not specify the complete list of them, and these types of contracts are composed of a variety of actions and activities by their essence" [9].

From these thoughts, it can be concluded that the result of the services is not material -item result, but the role of the contract can be visible. However, here the right question arises: is there any result (and what is the result) in the pecuniary service contract? Particularly, according to the order №-125 dated on July 3, 2017 of the Minister of internal affairs of the Republic of Uzbekistan, the Regulation approved "On the procedure for providing expert, research and information services to legal entities on the basis of payment by forensic-expert units of the Ministry of internal affairs ", accordingly, the paragraph 21 stipulates the statement that in case of acceptance of the order on the basis of payment by forensic-expert department , 15\% of the amount ( money) specified in the contract shall be paid in advance to the executor's account by the customer, and the remaining $85 \%$ shall be paid by the customer after the order is fulfilled. In this case, according to the terms of the contract, there are inconveniences for the customer in terms of payment terms and procedures, as well as excessive use of time. From this point of view, in our opinion, it would be useful to introduce the system of payments through the "Click" service, so that the implementation of this procedure does not lead to excessive labor and the precious time of the human factor.

Likewise, pecuniary services are carried out to the population on the contract basis by Patrol ling and post service units, the State units of the traffic safety, the Department of coordinating provision of the Safe tourism of the Ministry of internal affairs. There is a need to make additions and amendment $s$ to the contracts concluded with the participation of these sectors, as well as regulations related to the marking of costs of services. In this regard, we believe that it is necessary to develop a mechanism for possible types of services and the costs of them and the dissemination of this information to the public through the official 
mass media of the internal affairs bodies. This is by virtue of the population has access to information about the services, as well as the exact price provided by internal affairs bodies, which leads to increase the number of services.

Another rule that is tremendously topical when making the contract is the deadline set for the services provided in the contract. The requirements of the terms are reflected in the civil-legal contracts are extremely important because of ensuring the timely implementation of the rights of the subjects of these contracts. To simplify the statement, it is through the period that the participant $s$ of the civil-legal relationship become aware of their rights and obligations and realize the possibility of defending their interests within certain periods [10]. The analysis of the conflicts connected to civil-legal contracts that is presently considering in the economic courts shows that the reasons for the majority of them are the non-compliance of the side $s$ to the terms of the demands of the contract. One of the facts we have to pay extensive attention to is that the Chapter 38 of the $C C$ does not contain stipulation on the term of the contract in the pecuniary service contracts, nevertheless refers to the provisions of the contract. In particular, as emphasized by Academician Kh. Rakhmonkulov, counting the terms of limitations is important owing to the beginning, terminating, disconnecting, using, and clarifying the time of the claim period for the protection of the rights of citizens and legal entities in the judicial proceedings [11] .

Narmatov N.S states that Chapter 38 of the Civil Code does not reflect the rules applicable to the terms of service or other terms related to the requirement $\mathrm{s}$. He summarizes that the provisions on the terms of the contract and household contracts apply only to the pecuniary service contract from the reference norms set forth in the Article 708 of the Civil Code [12] . In addition, in view of the requirements of the Article 708 of the Civil Code, it can be assumed that the conditions apply the rules on the initial and final terms of the first part of the Article 635 of the Civil Code are also belong to the exist terms of the pecuniary service contracts, taking into account the subsidiary application of the general rules of the contract in relation to pecuniary service contracts.

On the other hand, the fact that the provisions of the contract on the terms of performance of works are applied to pecuniary service contracts does not always mean that it is expedient.

Based on the above mentioned statements, it can be concluded that the obligation to set terms of service in pecuniary service contracts is one of the important conditions, it is inexpedient to supplement the content of general rules of the household contract by subsidiary application.

The rights and obligations of the parties and the basis of liability also play vital role in making a contract.

Pecuniary service contract with the participation of the internal affairs bodies is concluded by sending a proposal to enter into the contract with the legal entity and the acceptance of this offer by the second side. It is essential to pay attention to all the terms of the contract, prepare the necessary documents and the type of service to be provided, and so forth in making a contract. Public security police units provide information to citizens and legal entities through mass 
media in advance of contract on services to ensure the safety of property, maintaining public order during public events, escorting goods, and services on concluding contracts in the system of internal affairs bodies (police) of foreign countries [13]. According to the legislation, contracts with the participation of units of the internal affairs bodies are concluded if they are made in the written form, signed by authorized persons, as well as if an agreement is reached between the parties on all-important terms of the contract.

D. I. Stepanov notes that making and amending the service contract (Chapter 39 of the Civil Code), in particular, the construction of the (model) contract, as a rule, is not regulated by applicable law and does not develop special (official) criteria for quality, just mediates compliance with applicable standards.

As general approach, such contract gives rise to an obligation on the part of the executor to expend maximum effort rather than an obligation to achieve the result[14] .

According to D.D. Khoshimov, there may be situations that force the sides to change or terminate the implementation of the contract in case the service contract comes into force[15] . In such cases, the requirements of the Article 382 of the Civil Code, namely the drastic change in the situation that was the basis for the side $s$ to make the contract, are grounds for modification or cancellation of the contract, unless otherwise provided by the contract or its essence. The serious change is the change in the situation to the extent that the side $s$ may not have entered into the contract at all or entered into it on many different terms when they knew in advance (Article 383, second part of the C C).
Besides, according to Article 382 of the Civil Code, pecuniary service contract may be amended or cancelled by the court at the request of one of the side $s$ only in the following cases: if the other party seriously breaches the contract; in other cases provided by this Code, other laws and the contract.

Terminating pecuniary service contract: the customer has the right to demand termination of the pecuniary service contract if the full price of services is paid, except in cases where the contract is terminated due to the fault of the executor.

The executor has the right to demand the termination of the pecuniary service contract if he pays all damages to the customer due to the termination of the contract, except in cases where the contract is terminated through the fault of the customer (Article 707 of the C C).

This rule depicts the right of the customer and the executor to refuse to perform the contract and its terms, as well as the permissible conditions. This rule applies when the refusal to perform the contract, irrelevant to the breach of their obligations by the sides.

The Article 707 of the Civil Code stipulates the right to terminate the contract when the customer pays the executor the full cost of services specified in the contract. The customer may terminate the contract before the provision of services, as well as during the provision of direct serv ices. It does not specify that the fixed cost may be denied in the payment process.

In our outlook, the customer is obliged to pay the full amount, regardless of whether the contract is terminated at the beginning of services or at the time of performance. The escort of tourists in transport and maintenance 
public order in the cultural heritage objects is done by the provision of safe tourism units of the internal affairs organs on the basis of pecuniary service contract, the legal entities may refuse the service at any time of the day, although the amount of money paid in full by travel agencies.

The executor may refuse to perform the contract provided that he / she pays all the damages caused to the customer as a result of the termination of the contract. Exception is, in case the contract is terminated through the fault of the customer. N.S. Narmatov gives the legal assessment of the termination of pecuniary service contracts as follows.

The first legal regulation depends on the termination of the pecuniary service contract by the customer, namely, the customer has the right to demand the termination of the pecuniary service contract, in case the contract is paid in full, except in cases where the contract is terminated due to the executor's fault (the first part of the Article 707).

The second legal regulation defines the right of the executor to demand the termination of the pecuniary service contract, in case $s /$ he pays all damages to the customer as a result of the termination of the contract [16] (the second part of the Article 707).

Termination of the pecuniary service contract on any grounds is incompatible with the stability of civil relation $\mathrm{s}$ and may only serve the interests of one side. C. A. Kabatov mentions that " unilateral refusal to perform the contract can be made only before the start of the term of performance of obligations under the contract"[17] .

On the contrary, M. C. Krotov argues that the sides, including the executor, as well as the customer, have the right to refuse pecuniary service contract at any time [18]. CONFIRMIT this view, Oh. N. Sadikov in his commentary to the Article 782 of the Civil Code of the Russian Federation depicts that if the time, which the sides may refuse to perform the contract, does not specify in this article in this case the services can be refused at any time before the provision of services [19].

In our opinion, it is necessary to set forth the norm that the term of service is specified in the contract in the context of the stipulation of the Article 707 of the Civil Code of the Republic of Uzbekistan;

According to N. S. Narmatov, the distribution of the "certain obligations" that arise from the parties due to the unilateral termination of the contract also causes hesitations. In fact, it is clear from the content of the Article 707 of the Civil Code that the legislature expressed concern for the interests of the customer. For instance, it is signed that if the customer has the right to demand the termination of pecuniary service contract in terms of the price of services is paid in full, in contrast, the executor has the righ $t$ to demand the termination of pecuniary service contract in case of the customer pays all damages marked owing to the cancellation of contract. In our view, s three sympathies prescribed by the legislature may lead to the disproportionate economic interest of the Execute and the customer in the presence of the professional participant in the Civil Proceedings [20] .

\section{CONCLUSION}

In conclusion, it is necessary to clarify the legal procedure for termination of this contract (Article 707 of the CC) since the termination of 
pecuniary service contract is not inextricably linked to th e breach of obligations by the sides of the contract .

In this case, the grounds for termination of the contract in accordance with the will of the parties should be clearly stated in the special norms of the Chapter 38 of the $\mathrm{CC}$ as a measure applied to the serious breach of contractual obligations in respect of certain types of pecuniary service contracts.

Additionally, the obligations of the side $s$ in the pecuniary service contracts should be provided with operational measures. The first step in this direction can be taken by the legislature to ensure the operational impact of the obligations of the executor to provide services of the required level of quality.

\section{REFERENCES}

1. Zokirov IB Civil law. Textbook. Team of authors. - T .: T SLI , 2009. P.328.

2. Rakhmonkulov Kh.R. The right of obligation (general rules). - Tashkent .: TSLI, 2005. P.237.

3. Commentary to the first part of the Civil Code of the Republic of Uzbekistan. - T .: TSLI, 2010. P.5.

4. Civil law: Textbook: In 2 volumes / Ed. E. A . Sukhanova . - Moscow, 1993. Vol .2. P.264.

5. Kabatov VA Compensated provision of services // Civil Code of the Russian Federation. Part 2. Text. Comments. Alphabetical subject index. -Moscow, 1996. P.393.

6. Ioffe OS Obligations right - Moscow, 1975. P.489.

7. Zavidov BD Intermediary service agreement. - Moscow, 1997. P.10.
8. Braginsky MI Making successive contract S and agreements . - Mosco w: Statute, 1998. P. 232.

9. Otakhonov F. The concept and essence of legal services to citizens and the subjects of businesses // «10 years of the Civil Code of Uzbekistan: experience and prospects for development: Proceedings of the International scientific-practical conference, November 27- 28, 2007. Tashkent, 2008. P. 200.

10. Ibratova FB The importance, essence and problems of civil-legal terms: Cand.of law sciences. ... diss. thesis. - Tashkent, 2008. P.4.

11. Rakhmonkulov Kh. General description and comments on the first part of the Civil Code of the Republic of Uzbekistan. Vol. I. Tashkent: "Economy and the world of law" publishing house, 1997. P.294.

12. Narmatov NS The problems of civil legal regulation of entrepreneurial activity in the field of services. Dis ... d octor of sciences in law , - T .: 2019. P.184.

13. Banina $O A$ Contractual relations with the participation of the internal affairs organs of the Russian Federation: On the example of the public security police: Abstract of the dissertation. Ministry of Internal Affairs of Russia. St. Petersburg University, 2004. P.14.

14. Stepanov DI Services as the object of civil rights: Dis. ... Cand. of law sciences: Moscow, 2004. P.315.

15. Khoshimov DD Services as the object of civil rights in accordance with the legislation of the Republic of Tajikistan: dissertation ... candidate of law sciences. Taj. nat. un-t Dushanbe, 2012. P.182.

16. Narmatov NS The problems of civil legal regulation of entrepreneurial activity in the 
field of services. Dis ... d octor of sciences in law , - T .: 2019. P. 253.

17. Kabatov VA Provision of pecuniary services (chapter 39) // Civil code. P II. Text, comments, alphabetic-subject index / Ed. OM Kozyr, AL Makovsky, SA Khokhlova. Moscow, 1996. P.396.

18. Civil law: Textbook. / Ed. AP Sergeeva, Yu.K. Tolstoy. - Moscow, 1998. Part 2. Pp .546-547.

19. Sadikov ON Commentary on Civil Law (article by article). Ch. 39. Provision of pecuniary services / Reference and information system "Garant".

20. Narmatov NS The problems of civil legal regulation of entrepreneurial activity in the field of services. Dis ... d octor of sciences in law , - T .: 2019. P. 184. 